\title{
The Integration of Life-Based Learning Based Local Wisdom in the Development of Innovative Biotechnology Learning Models
}

\author{
https://doi.org/10.3991/ijim.v14i12.15575 \\ Suratno $\left.{ }^{(}\right)$, Nurul Umamah, Erlia Narulita, Nurul Komaria, Khusnul Khotimah \\ University of Jember, Jember, Indonesia \\ suratno.fkip@unej.ac.id
}

\begin{abstract}
The development on biotechnology research is on the rapid growth. Biotechnology is assumed to be able to solve the needs problem in the community. University of Jember has developed a biotechnology research which focused on the fields of agricultural and health biotechnology. However, the result of biotechnology research has not been entirely integrated yet into the learning at schools, college, and community education. This research was intended to associate the products of biotechnology research with the innovative life-based local wisdom learning and developed local wisdom. Later on, the integration of life-based learning and local wisdom in regards to the development of biotechnology was able to be implemented at school, university and the community. Junior and senior high school, university and local community in East Java were selected as the subjects of this research. Ten-step model of developmental research was applied on this research (Borg and Gall, 1989) covering collecting research and information, planning, developing preliminary forms of product, testing the preliminary field, the revision on main product, testing the main field, the revision on operational product, testing the operational field, the revision of final product, and dissemination and implementation. The results of this research revealed that life-based learning model with local wisdom in the development of innovative biotechnology learning were valid, effective and efficient.
\end{abstract}

Keywords—Biotechnology, Life-Based Learning, Local Wisdom.

\section{Introduction}

The development of biotechnology research is in the rapid growth as the community assumes it is able to fulfil their needs. The science of biotechnology in the community can be developed through seminars. It refers to the interactive seminar discussing about various biotech information which is done by the experts to the public. It will bring up the significant benefits if the process of exchanging public knowledge is done well. The community is able to participate actively concerning the new solutions for innovative biotechnology [1]. Biotechnology brings about the discovery of new products in the fields of health and agriculture. After through the several repetitive and empirical processes, the discovery of this new product is able to be used for human health and the 
environment [2]. The development on the biotech research needs to do since its urgencies are about dealing with food security, climate change, poverty, environmental degradation which will be benefited from the development opportunities [3].

A biotechnology research has been developed by University of Jember whose emphasis was on the fields of agricultural and health biotechnology. However, the result of biotechnology research has not been entirely integrated yet into the learning at schools, college, and community education. The strength of biotechnology developed at school is for a certain thing. Biotechnology stays on the various processes and applications. Thus, biotechnology is very relevant to scientific education as [4], the students of secondary school located in western Australia were interested in the biotechnology especially in health care. Most of the students were able to answer and give arguments on the questionnaire given since they already understood the biotechnology. According to [5], the increase of students' understanding was affected by the level of teacher's literacy on biotechnology. Thematic teaching and learning analysis were used to evaluate the students' understandings on biotechnology. The lessons in which it let the students have a discussion about a topic with their peers. Learning through discussion leads to the changes in the students' understandings on biotechnology.

Biotechnology can be applied in many fields covering food, health care, agriculture, and environment. Biotechnology has social, ethical, and economic implications on its risks and benefits to human life and environment. Moreover, the effects of biotechnology on food and the environment are important to take into consideration. Therefore, studying biotechnology at secondary and high schools becomes as urgent as at any universities. Studying biotechnology provides the students a familiar understanding of the scientific knowledge of biotechnology and they are capable in implementing this knowledge to the community. The study model implemented to the biotech study is way to encourage the students to solve the life problems both individually and as groups and apply the knowledge as well as utilize the technology in improving its quality so that it will be responsible to surrounding environment [6].

Innovative learning has been developed. One of them is life-based learning with local wisdom that is a combination of knowledge and skills based on real life, to be creative in solving life's complete problems. Life-based learning focuses on widening its capabilities in the science era to cooperate for social welfare. The scientific ability offers the benefits of the type of knowledge to realize a life of togetherness. The emphasis of life-based learning is on the individual experiences about learning and the research on resources. Life-based learning is adaptive, facilitated, based on all life aspects and able to work on any strategies which suit you [7].

Local wisdom is defined as one of innovations and skills empowered in the learning process. Local wisdom has a relation on how the knowledge is obtained, secured, deducted, inherited and inherited. Learning which is related to local wisdom makes the students interested in learning and preserving the existing culture [8]. Local wisdom refers to local wealth which embodies the wisdom or the viewpoint of life. Local wisdom is able to form a person's personality since it consists of rules or the viewpoint of life. The integration of local wisdom in learning tends to be very effective and interesting [9]. 
Based on the above explanations, a research needed to integrate the innovative lifebased learning and local wisdom into the concept of biotechnology. Thus, connecting the products of biotech research with innovative life-based learning and developing local wisdom were expected to be done. So that, the integration of life-based learning and local wisdom was discovered to develop the biotech study in which the school, university and community took the advantages from it. This research obtained the life-based biotech model, the discovery of students' patterns, the learning activity of student and community related to health and agricultural biotechnology.

\section{Research Methods}

This research belongs to research development. The research growers were junior high schools, senior high schools, universities, and local communities in Jember, East Java, Indonesia 2019-2020. This research used ten stages of the research development model [10], which were research and information gathering, planning, initial product development, initial field testing, primary product revision, main field testing, operational product revision, operational field testing, final product revision, and dissemination and implementation. At the research and information gathering stage, there was a needs analysis and literature review. The needs analysis was done by disseminating the analysis needed to identify the problem in the field. A literature review was done by gathering information from various accurate sources. The planning stage was to construct designs such as formulating objectives, determining learning models to be developed, and identifying activities carried out at each stage of research. The basis of the product was to develop data collection instruments in the database. The initial field testing stage resulted in draft one and limited testing, which means nothing. If this stage met the valid criteria, it reached concept 3 . At the field testing stage, field tests were applied to find the effectiveness of the learning developed. While in the remote field testing stage, this research only led to the product stage. The type of data used in this research was data obtained from validation of life-based learning with local wisdom model, syllabus-validation sheets, lesson plans, learning achievements, the number of student responses following the study, teacher response rates, criticisms and suggestions to improve the development model. The procedure to develop biotechnology with local wisdom learning can be seen in Figure 1. 


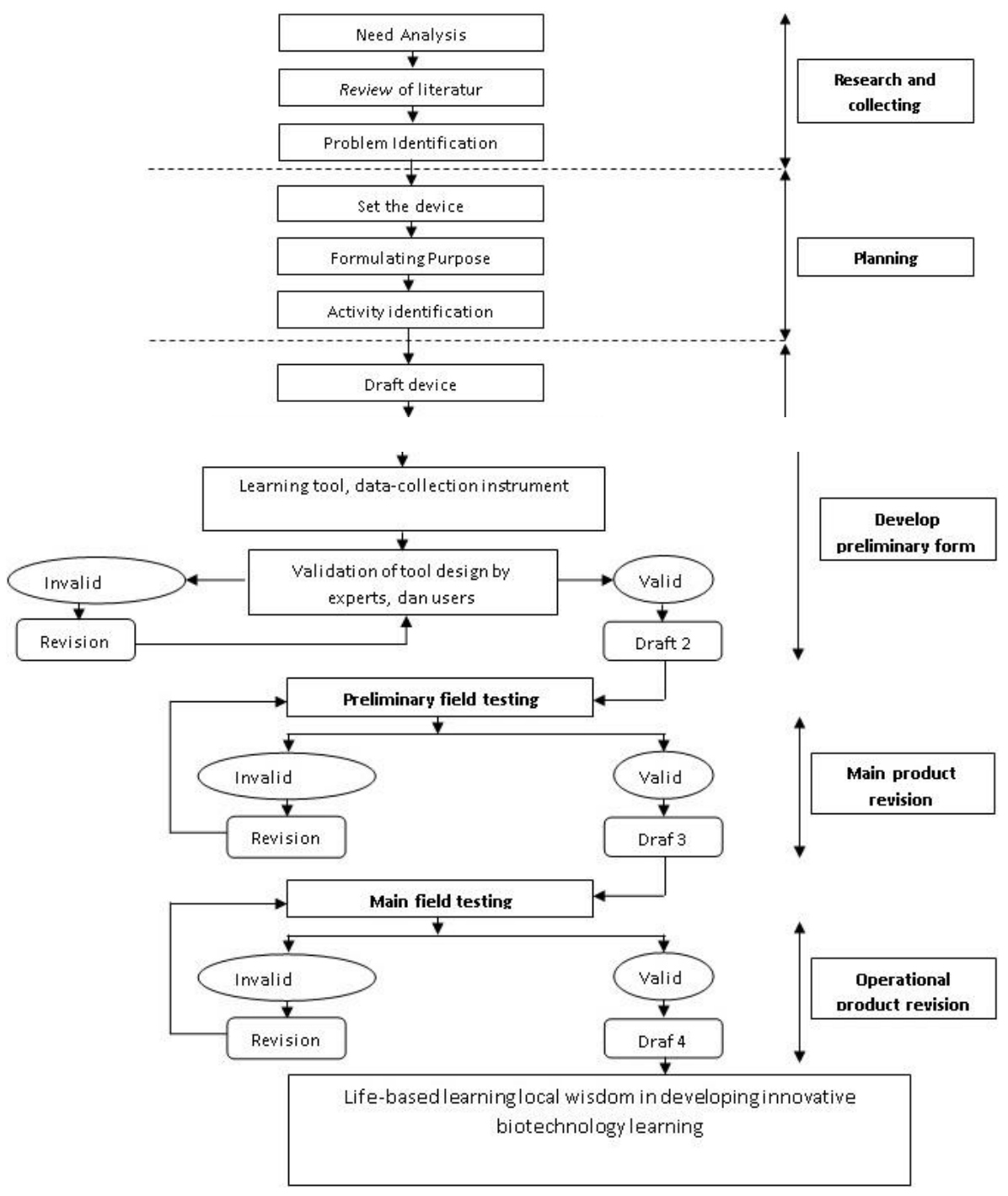

Fig. 1. A research procedure based on a Borg and Gall development model

\subsection{Validity}

The type of data used in this research was data obtained from the validation of local wisdom-based learning, lesson plans, learning achievements, student response rates, and teacher response numbers. After the initial product form, the ranking was done with the following criteria:

1. Score 4 , when the validator gives an excellent rating 
2. Score 3, when the validator gives a good rating

3. Score 2 , when the validator gives a bad rating

4. Score 1 , when the validator gives an abysmal rating

Data obtained from the results were analyzed using a technique for presenting data analysis.

$$
V=\frac{T E S}{T M S} \times 100 \%
$$

Information:

$\mathrm{V} \quad=$ Percentage rating

TSE = Total empirical score obtained

$\mathrm{TSM}=$ Total maximum score

The percentage of data obtained using the formula above was converted to descriptive qualitative data using the assessment criteria in Table 1

Table 1. Criteria for validating life-based learning based local wisdom

\begin{tabular}{|c|l|l|l|}
\hline No & \multicolumn{1}{|c|}{ Percentage (\%) } & \multicolumn{1}{|c|}{ Category } & \multicolumn{1}{|c|}{ Adjudgment } \\
\hline 1 & $81,25 \leq \mathrm{x}<100$ & Very valid & $\begin{array}{l}\text { The product becomes available on the ground for real } \\
\text { learning activities }\end{array}$ \\
\hline 2 & $62,5 \leq \mathrm{x}<81,25$ & Valid & $\begin{array}{l}\text { The product may continue by adding something less, } \\
\text { doing certain considerations of addition less substan- } \\
\text { tial and less fundamental }\end{array}$ \\
\hline 3 & $43,75 \leq \mathrm{x}<62,5$ & A poor valid & $\begin{array}{l}\text { Revise by carefully reviewing and looking for specific } \\
\text { weaknesses of the product to be perfected }\end{array}$ \\
\hline 4 & $25 \leq \mathrm{x}<43,75$ & Invalid & $\begin{array}{l}\text { Revised broadly and fundamentally about the content } \\
\text { of the product }\end{array}$ \\
\hline
\end{tabular}

The validation criteria above were modified criteria. If the results obtained from the validation reached a score of 62.5 , then the development product made was further developed by adding something that was lacking.

\subsection{Effectiveness}

Besides categorizing, to get the value of learning outcomes, researchers used the normalized gain $(\mathrm{g})$ formula. This was the normalized profit formula [11].

$$
\text { Normalized gain }(g)=\frac{\text { Final Scores-Initial Scores }}{\text { Maximal Scores-Inicial Scores }}
$$

The value scale used in the normalized data gain $(\mathrm{g})$ is in table 2 below.

Table 2. Criteria of Normalized gain (g)

\begin{tabular}{|l|l|}
\hline \multicolumn{1}{|c|}{ Score Normalized gain } & \multicolumn{1}{c|}{ Criteria Normalized gain } \\
\hline $0,70<$ normalized gain & Upper \\
\hline $0,30<$ normalized gain $<0,70$ & Moderate \\
\hline normalized gain $<0,30$ & Lower \\
\hline
\end{tabular}




\subsection{Practicality}

The percentage of teacher and student responses was calculated using the following formula.

$$
\text { Percentage }=\frac{\text { Scores Obtained }}{\text { SMaximum Scores }} \times 100 \%
$$

Feasibility percentage of the learning tools developed from educator analysis and student responses, which was then converted into qualitative data using table 3 criteria

Table 3. Educators and criteria of student response

\begin{tabular}{|c|l|l|}
\hline No & \multicolumn{1}{|c|}{ Percentage } & \multicolumn{1}{c|}{ Category } \\
\hline 1 & $81,25 \leq \mathrm{x}<100$ & Very good \\
\hline 2 & $62,5 \leq \mathrm{x}<81,25$ & Good \\
\hline 3 & $43,75 \leq \mathrm{x}<62,5$ & Less good \\
\hline 4 & $25 \leq \mathrm{x}<43,75$ & Not good \\
\hline
\end{tabular}

\section{Result}

In developing a learning model, the first thing to do was to analyze the needs and review the literature included in the information gathering stage. Initial product development was carried out by formulating objectives, identifying activities, and designing learning models, then followed by making a guidebook, making a set of models, and making data collection instruments. When the product was finished, the instrument was validated and followed by product validation. The validated research instruments consisted of validation of a Life-based integrated learning handbook with local wisdom in the development of innovative biotechnology learning models for experts and practitioners, syllabus validation sheets, learning implementation plans, learning achievement tests, teacher questionnaire responses, student responses, questionnaire, and observation guide sheet. The instrument validation stage obtained data in quantitative and qualitative forms.

\subsection{Validity}

The percentage of teacher and student responses was calculated using the following formula. 
Table 4. Instrument Validation Results

\begin{tabular}{|c|l|c|c|c|}
\hline No & \multicolumn{1}{|c|}{ Instrument } & $\begin{array}{c}\text { Percentage } \\
(\mathbf{\%})\end{array}$ & Category & Category \\
\hline 1 & $\begin{array}{l}\text { Instrument Validation Sheet handbook of integration of life- } \\
\text { based learning on local wisdom by experts }\end{array}$ & $91,6 \%$ & Very Valid & No Revision \\
\hline 2 & $\begin{array}{l}\text { Instrument Validation Sheet for expert integration of life- } \\
\text { based learning on local wisdom }\end{array}$ & $95,8 \%$ & Very Valid & No Revision \\
\hline 3 & Learning Implementation Plan Validation Instrument sheet & $97,9 \%$ & Very Valid & No Revision \\
\hline 4 & Syllabus Validation Instrument sheet & $95 \%$ & Very Valid & No Revision \\
\hline 5 & Instrument Validation of learning outcomes tests sheet & $95 \%$ & Very Valid & No Revision \\
\hline
\end{tabular}

The average validation result of all instruments was $95.06 \%$ with a very valid category. Therefore, because the results of the validation hasmet the standards, all instruments can be used for the next stage. The results obtained are not only quantitative but also qualitative data. Qualitative data in the form of criticisms and suggestions from theValidatorand the results of revisions to the research instruments can be seen in Table 5 .

Table 5. Critics and Suggestions given by Validators for Research Instruments

\begin{tabular}{|c|c|c|c|}
\hline No & Instrument & Critics and suggestions & Revision Results \\
\hline 1 & $\begin{array}{l}\text { Validation sheet of } \\
\text { learning model } \\
\text { manuals by experts }\end{array}$ & $\begin{array}{l}\text { The size of the manual text } \\
\text { font is too small }\end{array}$ & $\begin{array}{l}\text { The size of the text of the study guide } \\
\text { book is enlarged from size } 12 \text { to } 16\end{array}$ \\
\hline 2 & $\begin{array}{l}\text { Validation sheet } \\
\text { for learning model } \\
\text { development }\end{array}$ & $\begin{array}{l}\text { In developing models, the } \\
\text { syntax must be clear }\end{array}$ & $\begin{array}{l}\text { In the handbook, the syntax written in } \\
\text { the learning activities has been added }\end{array}$ \\
\hline 3 & $\begin{array}{l}\text { Validation sheet } \\
\text { for learning imple- } \\
\text { mentation plan }\end{array}$ & $\begin{array}{l}\text { The format of the lesson plan } \\
\text { is improved, adjusted to } \\
\text { Ministry of Education } \\
\text { Regulation No. } 40 \text { of } 2007 \\
\text { (regarding the standard } \\
\text { process) }\end{array}$ & $\begin{array}{l}\text { The lesson plans that have been } \\
\text { developed by researchers are revised, } \\
\text { spelled out from the syllabus to direct } \\
\text { learning activities that foster subject } \\
\text { identity and learning resources that pay } \\
\text { attention to participants' backgrounds } \\
\text { students, encourage active } \\
\text { participation and pay attention to the } \\
\text { principles of interrelation and } \\
\text { cohesiveness. }\end{array}$ \\
\hline 4 & $\begin{array}{l}\text { Syllabus validation } \\
\text { sheet }\end{array}$ & $\begin{array}{l}\text { Validated components can be } \\
\text { adjusted to Ministry of } \\
\text { Education Regulation No. } 40 \\
\text { of } 2007 \text { (regarding process } \\
\text { standards) }\end{array}$ & $\begin{array}{l}\text { Syllabus that has been made by } \\
\text { researchers is adapted to Permendiknas } \\
\text { no. } 40 \text { of } 2007 \text { as a reference for the } \\
\text { development of lesson plans. }\end{array}$ \\
\hline 5 & $\begin{array}{l}\text { Learning outcomes } \\
\text { tests validation } \\
\text { sheet }\end{array}$ & $\begin{array}{l}\text { It should be noted variations } \\
\text { and the level of difficulty of } \\
\text { the questions }\end{array}$ & $\begin{array}{l}\text { Variations in the level of difficulty are } \\
\text { evenly distributed }\end{array}$ \\
\hline
\end{tabular}

The instrument was a study on Tables 4 and 5 with minor revisions that were used for the next stage, product validation by experts and practitioners. 
Table 6. Product Validation by Experts

\begin{tabular}{|c|c|c|c|c|c|}
\hline No & Validator & Instrument & $\begin{array}{c}\text { Percentage } \\
(\%)\end{array}$ & Category & Category \\
\hline \multirow[b]{2}{*}{1} & Expert & \multirow{2}{*}{$\begin{array}{l}\text { Validation of textbooks on } \\
\text { integration of life-based learning on } \\
\text { local wisdom by experts }\end{array}$} & 85.7 & \multirow[b]{2}{*}{$\begin{array}{l}\text { Very } \\
\text { Valid }\end{array}$} & \multirow[b]{2}{*}{$\begin{array}{l}\text { No } \\
\text { Revision }\end{array}$} \\
\hline & Teacher & & 84.02 & & \\
\hline \multirow{2}{*}{2} & Expert & \multirow{2}{*}{ Development Validation } & 89.5 & \multirow{2}{*}{$\begin{array}{l}\text { Very } \\
\text { Valid }\end{array}$} & \multirow{2}{*}{$\begin{array}{l}\text { No } \\
\text { Revision }\end{array}$} \\
\hline & Teacher & & 84.3 & & \\
\hline \multirow{2}{*}{3} & Expert & \multirow{2}{*}{$\begin{array}{l}\text { Learning implementation plan } \\
\text { Validation }\end{array}$} & 96.38 & \multirow{2}{*}{$\begin{array}{l}\text { Very } \\
\text { Valid }\end{array}$} & \multirow{2}{*}{$\begin{array}{l}\text { No } \\
\text { Revision }\end{array}$} \\
\hline & Teacher & & 85 & & \\
\hline \multirow{2}{*}{4} & Expert & \multirow{2}{*}{ Syllabus validation } & 93.9 & \multirow{2}{*}{$\begin{array}{l}\text { Very } \\
\text { Valid }\end{array}$} & \multirow{2}{*}{$\begin{array}{l}\text { No } \\
\text { Revision }\end{array}$} \\
\hline & Teacher & & 92.2 & & \\
\hline \multirow{2}{*}{5} & Expert & \multirow{2}{*}{$\begin{array}{l}\text { Test validation of learning } \\
\text { outcomes }\end{array}$} & 94 & \multirow{2}{*}{$\begin{array}{l}\text { Very } \\
\text { Valid }\end{array}$} & \multirow{2}{*}{$\begin{array}{l}\text { No } \\
\text { Revision }\end{array}$} \\
\hline & Teacher & & 92.8 & & \\
\hline
\end{tabular}

Based on Table 6, the average overall product by experts and practitioners was $89.1 \%$ with a very valid category. The results obtained were not only quantitative data but also qualitative data. Qualitative data in the form of criticisms and validators' suggestions were given for products to be developed. Suggestions and critics from validators on the product can be seen in Table 7 .

Table 7. The research validator gave suggestions to the product

\begin{tabular}{|c|c|c|c|c|}
\hline No & Product & Validator & $\begin{array}{c}\text { Criticism and } \\
\text { suggestions }\end{array}$ & Revision Results \\
\hline \multirow[b]{3}{*}{1} & \multirow[b]{3}{*}{$\begin{array}{l}\text { Integration } \\
\text { model of life- } \\
\text { based learning } \\
\text { on local } \\
\text { wisdom (Guide } \\
\text { book) }\end{array}$} & Expert 1 & $\begin{array}{l}\text { In the manual written } \\
\text { the name of the } \\
\text { supervisor }\end{array}$ & The guide's name has been added \\
\hline & & Expert 2 & $\begin{array}{l}\text { The size of the manual } \\
\text { text font is too small }\end{array}$ & $\begin{array}{l}\text { In the handbook, discussion has } \\
\text { been added at each phase relating } \\
\text { to local wisdom }\end{array}$ \\
\hline & & Expert 3 & $\begin{array}{l}\text { In the guide book, in } \\
\text { chapter } 3 \text { there are } \\
\text { "characteristics of the } \\
\text { integration of life- } \\
\text { based learning model } \\
\text { on local } \\
\text { wisdom ". Life-based } \\
\text { learning and local } \\
\text { wisdom are not clearly } \\
\text { written in this section }\end{array}$ & $\begin{array}{l}\text { An original life-based learning } \\
\text { characteristic material has been } \\
\text { added to books that have been } \\
\text { developed }\end{array}$ \\
\hline \multirow[t]{2}{*}{2} & \multirow[t]{2}{*}{ Development } & Expert 3 & $\begin{array}{l}\text { In developing the } \\
\text { model, each phase is } \\
\text { added to the } \\
\text { discussion }\end{array}$ & $\begin{array}{l}\text { In the handbook, discussion has } \\
\text { been added at each phase relating } \\
\text { to local wisdom }\end{array}$ \\
\hline & & Expert 1 & $\begin{array}{l}\text { In developing models, } \\
\text { the syntax must be } \\
\text { clear }\end{array}$ & $\begin{array}{l}\text { In the handbook, the syntax written } \\
\text { in the learning activities has been } \\
\text { added }\end{array}$ \\
\hline 3 & Syllabus & Expert 1 & $\begin{array}{l}\text { Identity writing must } \\
\text { be complete }\end{array}$ & $\begin{array}{l}\text { Writing the junior high school } \\
\text { identity that will be used for } \\
\text { limited tests / field tests has been } \\
\text { written on the syllabus }\end{array}$ \\
\hline
\end{tabular}




\begin{tabular}{|c|c|c|c|c|}
\hline & & Expert 2 & $\begin{array}{l}\text { The form of } \\
\text { assessment needs to } \\
\text { be adjusted and more } \\
\text { detailed }\end{array}$ & $\begin{array}{l}\text { The form of assessment has been } \\
\text { adjusted, the test assessment is } \\
\text { filled with essays }\end{array}$ \\
\hline \multirow{6}{*}{4} & \multirow{6}{*}{$\begin{array}{l}\text { Learning } \\
\text { Implementation } \\
\text { Plan }\end{array}$} & Expert 1 & $\begin{array}{l}\text { In implementing } \\
\text { learning, there must be } \\
\text { an observer } \\
\text { To achieve learning } \\
\text { objectives must use } \\
\text { more than one } \\
\text { learning method }\end{array}$ & $\begin{array}{l}\text { When conducting limited tests and } \\
\text { field tests each meeting always } \\
\text { brings an observer to find out the } \\
\text { implementation of learning } \\
\text { Added several methods, namely } \\
\text { assignment, question and answer, } \\
\text { lecture, discussion and presentation }\end{array}$ \\
\hline & & Expert 2 & $\begin{array}{l}\text { In the lesson plan } \\
\text { must write the } \\
\text { learning model used }\end{array}$ & $\begin{array}{l}\text { An learning implementation plan } \\
\text { has been added to the " integration } \\
\text { model of life-based learning on } \\
\text { local wisdom " }\end{array}$ \\
\hline & & Expert 3 & $\begin{array}{l}\text { Learning implementa- } \\
\text { tion plan writing } \\
\text { format improved }\end{array}$ & $\begin{array}{l}\text { The format of the lesson plan is } \\
\text { refined by writing the indicators } \\
\text { and then the learning objectives }\end{array}$ \\
\hline & & Teacher 1 & $\begin{array}{l}\text { In the method, writing } \\
\text { is adjusted and } \\
\text { ordered according to } \\
\text { syntax }\end{array}$ & $\begin{array}{l}\text { In the method written: assignments, } \\
\text { questions and answers, lectures, } \\
\text { discussions and presentations }\end{array}$ \\
\hline & & Teacher 2 & $\begin{array}{l}\text { To be neat, the learn- } \\
\text { ing implementation } \\
\text { plan format uses } 1 \\
\text { space when } \\
\text { writing tables }\end{array}$ & $\begin{array}{l}\text { The learning implementation plan } \\
\text { format uses } 1 \text { space in the table }\end{array}$ \\
\hline & & Teacher 3 & $\begin{array}{l}\text { The image in the } \\
\text { lesson plan is too } \\
\text { small }\end{array}$ & $\begin{array}{l}\text { The image in the learning imple- } \\
\text { mentation plan is enlarged so that } \\
\text { the eye appears }\end{array}$ \\
\hline \multirow{3}{*}{5} & \multirow{3}{*}{$\begin{array}{l}\text { Learning } \\
\text { Outcomes Test }\end{array}$} & Expert 2 & $\begin{array}{l}\text { It needs to be revised } \\
\text { on the variation of } \\
\text { questions and the level } \\
\text { of difficulty }\end{array}$ & $\begin{array}{l}\text { The variation of the questions and } \\
\text { the level of difficulty of the } \\
\text { questions are distributed evenly }\end{array}$ \\
\hline & & Expert 3 & $\begin{array}{l}\text { In the question box } \\
\text { "when students are } \\
\text { given the assignment } \\
\text { to make products like } \\
\text { question number } 1 \mathrm{~b} \text {, } \\
\text { the cognitive level is } \\
\text { not } \mathrm{C} 2 \\
\text { In question no. } 2 \mathrm{a} \text {, the } \\
\text { cognitive level for the } \\
\text { problem mentions the } \\
\text { example of consumer } \\
1 \text { found in the } \\
\text { environment that is } \mathrm{C} 4\end{array}$ & $\begin{array}{l}\text { C6 is replaced by the cognitive } \\
\text { level because students are assigned } \\
\text { to make products from what they } \\
\text { already know from reading } \\
\text { In the louvers replaced C4 }\end{array}$ \\
\hline & & Teacher 1 & $\begin{array}{l}\text { On the test results of } \\
\text { learning outcomes } \\
\text { should be written time } \\
\text { allocation }\end{array}$ & $\begin{array}{l}\text { In the Learning Outcomes Test } \\
\text { added time allocation }\end{array}$ \\
\hline
\end{tabular}

Based on the result of validation and revision toward the research product, the integration model of life-based learning with local wisdom could be claimed as valid so that the product could be tested in a big group test. 


\subsection{Effectiveness}

The limitation of the data on cognitive learning achievement obtained from the pretest and posttest scores can be seen on Table 8 .

Table 8. Cognitive learning achievement of Field test / Big group test

\begin{tabular}{|c|l|c|c|c|c|}
\hline No & \multicolumn{1}{|c|}{$\begin{array}{c}\text { Cognitive Learning } \\
\text { Outcomes }\end{array}$} & $\begin{array}{c}\text { Total } \\
\text { students }\end{array}$ & $\begin{array}{c}\text { Average } \pm \\
\text { SD }\end{array}$ & $\begin{array}{c}\text { Normalized } \\
\text { gain (g) }\end{array}$ & Category \\
\hline 1 & Pre-test & 57 & $46.1 \pm 19.5$ & 0.49 & $\begin{array}{l}\text { Medium } \\
\text { category }\end{array}$ \\
\hline 2 & Post-test & 57 & $72.3 \pm 10.8$ & & \\
\hline
\end{tabular}

Based on Table 8, it can be seen that the result of the students' posttest score of cognitive learning achievement was higher than the pretest score. The mean score of pretest was 46.1 while the posttest was 72.3. Normalized gain (g) for the result of cognitive learning achievement on big group was 0.49 and it was categorized as moderate.

\subsection{Practicality}

The result of big group tests contained data of teacher responses toward the integration model of life-based learning with local wisdom, and it can be seen in Table 9

Table 9. Data of teachers' responses toward the integration model of life-based learning with local wisdom through the big group test/field test

\begin{tabular}{|c|l|c|l|}
\hline No & \multicolumn{1}{|c|}{ Indicator } & Average & Category \\
\hline 1 & Achievement of competencies and learning objectives & 90 & Very good \\
\hline 2 & Student Response & 75 & Well \\
\hline 3 & Degree of Difficulties in Implementing & 91.6 & Very good \\
\hline 4 & Adequacy of Time & 100 & Very good \\
\hline Average Teacher Response & 89.1 & Very good \\
\hline
\end{tabular}

The data of students' responses are presented in Table 10

Table 10. Data of students' responses toward the integration model of life-based learning with local wisdom in the big group test

\begin{tabular}{|c|l|c|l|}
\hline No & \multicolumn{1}{|c|}{ Indicator } & Average & Category \\
\hline 1 & Interest in learning & 71.9 & Well \\
\hline 2 & Usefulness in learning & 71.6 & Well \\
\hline 3 & Interest in learning the next chapter & 82.4 & Very good \\
\hline \multicolumn{2}{|l|}{ Average student response } & 75.3 & Well \\
\hline
\end{tabular}

Data of students' responses on the integration model of life-based learning with local wisdom in the big group test showed the average of learning interest was moderate of 71.9 , the advantage of joining the learning for the next chapter was good of 71.6. The average interest in following the learning for the next chapter was excellent at 82.4. Based on the big group test, the integration model of life-based learning with local wisdom could be implemented for a proper analysis. 


\section{$4 \quad$ Result}

Good learning is one that is based on the students' needs. The learning which is in line with the students' needs can create a meaningful leaning for them [12]. The learning model should consider the students' condition and able to make the students motivated to study harder [13]. The integration of life-based learning with local wisdom is an attempt to prepare the people who have a high sense of competing, excellent potential to improve daily economic life that can be developed through a good education [14]. The integration of life-based learning also encourages the students to get log-life knowledge or skills through education, training, work experience, and life [7].

Sustainable life-based learning is based on local wisdom developed and combined as well as added with biotechnology learning is valid. A valid product can be used on a big scale test. The implementation of the product during the big scale test showed no obstacles. The students were very interested, enthusiastic, and motivated during the study. Life-based learning involved the students' daily life, so they were able to develop their cognitive ability. Innovative project in the learning enhances the students' learning achievement [15]. By having them as active learners in the learning process, their central cognition will be modulated positively by the discovery process [16].

Based on the research that had been conducted, the mean score of the posttest was higher than the pretest. The life-based learning caused it to put the basis on local wisdom. The learning utilized the element of local wisdom to create an interactive atmosphere, fun learning that made the students understand local wisdom better [17]. The local wisdom was much about education. It influenced the position if it was related to learning. It made the students learning directly toward daily life with a contextual experience [18]. In addition, contextual experience can also be done with a virtual reality laboratory (VR) by manipulating objects in virtual scenes that resemble the real world [19]. Virtual reality (VR) laboratory implementation can be done using a tablet, PC or smartphone that can be accessed anytime and anywhere [20].Contextual experience obtained by using cellular features, which was following the learning environment, so the integration of pedagogical and technology elements became complex [21], and the use of multimedia contributed to the level of understanding of the material [22]. The task of the teacher in this case needs to be reminded the use of digital technology needs to be balanced with humanistic literacy so as not to violate digital ethics [23]. Therefore, it had an impact positively on the learning achievement of biotechnology. One of the examples of innovative biotechnology learning based on local wisdom with the integration of life-based learning was the process of makingTempe.

The students' and teachers' responses in having life-based learning with local wisdom with the inclusion of biotechnology literacy learning were good. It means that the innovation of learning that had been developed was accepted entirely. Teachers need to develop innovation in learning, especially for biotechnology. The innovation in learning should improve the productivity and efficiency of the learning itself. It can be in various forms [24]. 


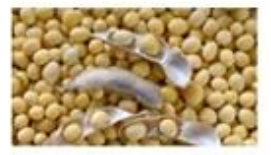

Soybean seeds Source : liputan6.com

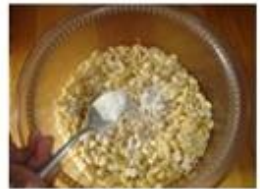

Giving yeast to soybean seeds Source : tasty-indonesian-food com

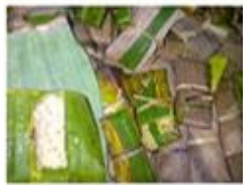

Tempeh wrapped in banana leaves Source : mypangandaran com

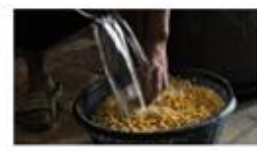

Washing soybeans Source : tempeongis-87.blogspot.oom

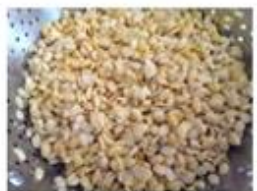

Drain the soybeans

Source : Jardinvegancom

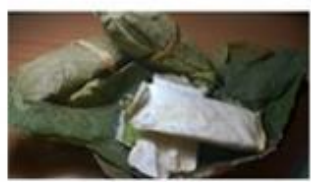

Tempeh wrapped in teak leaves Source : Hipwee com
Soaking soybeans

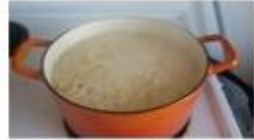

Cook soybeans until soft Sourse : tempedikanada.blogspotcom
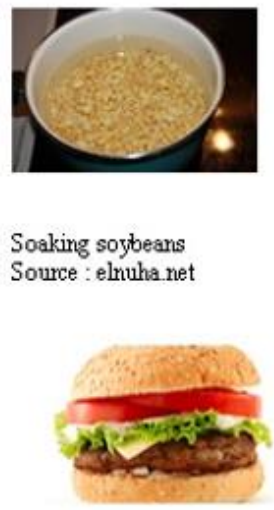

Burger Termpe Source : Hitbongetcom

One of them is life-based learning with local wisdom for innovative biotech studies. Biotechnology fulfilled an integral part of human civilization, which has an essential position in scientific research [25]. Therefore, there is no reason for the teachers to argue that the obstacles of biotechnology learning are the limitation of materials and resources. The teacher training program should be more innovative and avoid discussing biotechnology topic [26].

\section{Conclusion}

The result showed that biotechnology material in the school have not fully developed life-based learning. Innovative biotechnology learning concepts have been discovered by integrating local wisdom is valid, practical, and effective in Junior and Senior high schools, university and local community learning in Jember. The learning tool of biotechnology that had been developed included lesson plan, learning material, worksheet, and evaluation, all of them were integrated with valid life-based learning, and it was appropriate based on the local wisdom-based innovative learning.

\section{Acknowledgement}

We would like to acknowledge the support from Islamic Development Bank (IsDB) 2019. 


\section{$7 \quad$ References}

[1] Malyska A, Bolla R, \& Twardowski, T. (2016). The Role of Public Opinion in Shaping Trajectories of Agricultural Biotechnology. Trends in Biotechnology, Month Year, Vol. xx, No. $y y$, 5. https://doi.org/10.1016/j.tibtech.2016.03.005

[2] Preston, C. J., \& Wickson, F. (2016). Broadening the lens for the governance of emeging technologies: Care etnics and agricultural biotechnology. Technology in Society, 48-57. https://doi.org/10.1016/j.techsoc.2016.03.001

[3] ECLAC. (2010). A study on applicability of biotechnology to development in the caribbean: opportunities and risks. Economic Commission for Latin America and the Caribbean, 1-33.

[4] Lieshout, E. v., \& Dawson, V. (2016). Knowledge of, and Attitudes Towards Healthrelated Biotechnology Applications Amongst Australian Year 10 High School Students. Journal of Biological Education, 1-17. https://doi.org/10.1080/00219266.2015.1117511

[5] Anderton, B. N., \& Ronald, P. C. (2017). Hybrid thematic analysis reveals themes for assessing student understanding of biotechnology. Journal of Biological Education, 1-13. https://doi.org/10.1080/00219266.2017.1338599

[6] Nurlaely, N., Permanasari, A., \& Riandi, R. (2017). Student's STEM Literacy in Biotechnology Learning at Junior High School. International Conference on Mathematics and Science Education (ICMScE), 1-6. https://doi.org/10.1088/1742-6596/895/1/0121 $\underline{55}$

[7] Staron, M. (2011). Life-based learning model - a model for strength -based approaches to capability development and implications for personal development planning. Mindful Creations, 1-14.

[8] Selasih, N. N., \& Sudarsana, I. K. (2018). Education Based on Ethnopedagogy in Maintaining and Conserving the Local Wisdom: A Literature Study. The International Journal of Social Science, 293-306. https://doi.org/10.26811/peuradeun.v6i2.219

[9] Albantani, A. M., \& Madkur, A. (2018). Think Globally, Act Locally: The Strategy of Incorporating Local Wisdom in Foreign Language Teaching in Indonesia. International Journal of Applied Linguistics \& English Literature, 1-8. https://doi.org/10.7575/aiac.ij alel.v.7n.2p.1

[10] Borg, W. R., \& Gall, M. D. (1989). Educational Research: an Introduction. New York: Longman.

[11] Meltzer, D. E. (2005). Relation between students' problem-solving performance. American Association of Physics Teachers, 463-478. http://dx.doi.org/10.1119/1.1862636

[12] Warsono, Nursuhud, P. I., Darma, R. S., Supahar, Oktavia, D. A., Setiyadi, A., \& Kurniawan, M. A. (2020). Multimedia Learning Modules (MLMs) Based on Local Wisdom in Physics Learning to Improve Student Diagram Representations in Realizing the Nature of Science. $\quad i J I M \quad$ - Vol. 14, No. 6, 148-158. https://doi.org/10.3991/ijim.v14i06. $\underline{11640}$

[13] Bruno, A., \& Dell'Aversana, G. (2017). Reflective practicum in higher education: the influence of the learning environment on the quality of learning. Assessment \& Evaluation in Higher Education, 1-15. https://doi.org/10.1080/02602938.2017.1344823

[14] Suwono, H., Mahmudah, A., \& Maulidiah, L. (2017). Scientific Literacy of a Third Year Biology Student Teachers: Exploration Study. International Conference on Language, Society and Culture in Asian Contexts, 269-278. https://doi.org/10.18502/kss.v1i3.747

[15] Kavacik, L., Surmeli, H., \& Yelken, T. Y. (2015). Innovation Practices in Elementary School Science and Technology Course and Their Effects on Students. Education and Science, 247263. https://doi.org/10.15390/eb.2015.2613 
[16] Martins, M. J., \& Martel, F. (2013). An innovative laboratory research practice supporting an introduction to research methodology in the medical undergraduate curriculum: the students' perspective. Journal of Contemporary Medical Education, 3-8. https://doi.org/ 10.5455/jcme.20121116104951

[17] Abadi, M. K., Asih, E. M., \& Jupri, A. (2018). The Development of Interactive Mathematics Learning Material Based on Local Wisdom with .swf Format. 4th International Seminar of Mathematics, Science and Computer Science Education, 1-7. https://doi.org/10.1088/17426596/1013/1/012131

[18] Hartini, S., Firdausi, S., Misbah, \& Sulaeman, N. F. (2018). The development of physics teaching materials based on local wisdom to train saraba kawa characters. Jurnal Pendidikan IPA Indonesia, 130-137. https://doi.org/10.15294/jpii.v7i2.14249

[19] Ikhsan, J., Sugiyarto, K. H., \& Astuti, T. N. (2020). Fostering Student's Critical Thinking through a Virtual Reality Laboratory . iJIM-Vol. 14, No. 8, 183-195. https://doi.org/10.3 991/ijim.v14i08.13069

[20] Bukhori, B. (2019). The Effect of Smartphone Addiction, Achievement Motivation, and Textbook Reading Intensity on Students' Academic Achievement . iJIM - Vol. 13, No. 9, 66-80. https://doi.org/10.3991/ijim.v13i09.9566

[21] Al-Hunaiyyan, A., Al-Sharhan, S., \& Alhajri, R. (2017). A New Mobile Learning Model in the Context of Smart Classroom Environment: A Holistic Approach. iJIM - Vol. 11, No. 3, 39-56. https://doi.org/10.3991/ijim.v11i3.6186

[22] Atan, N. A., , Said, M. N., Ali, M. F., Mohd, S., \& Hamid, M. Z. (2018). Integrating Animations in Chinese Character Writing Based on Cognitive Theory of Multimedia Learning to Promote Students' Writing Skills . IJIM - Vol. 12, No. 7, 97-111. https://doi. org/10.3991/ijim.v12i7.9671

[23] Sari, D. I., Rejekiningsih, T., \& Muchtarom, M. (2020). Students' Digital Ethics Profile in the Era of Disruption: An Overview from the Internet Use at Risk in Surakarta City, Indonesia . iJIM - Vol. 14, No. 3, 82-94. https://doi.org/10.3991/ijim.v14i03.12207

[24] Serdyukov, P. (2017). Innovation in education: what works, what doesn't, and what to do about it. Journal of Research in Innovative Teaching \& Learning, Vol. 10 Issue: 1, 4-33. https://doi.org/10.1108/jrit-10-2016-0007

[25] Kumar, V., Rout, S., Tak, M. K., \& Deepak, K. (2015). Application of Biotechnology in Forestry: Current Status and Future Perspective. Nature Environment and Pollution Technology, 645-653.

[26] Fonseca, M. J., Costa, P., Lencastre, L., \& Tavares, F. (2012). Disclosing biology teachers' beliefs about biotechnology and biotechnology education. Teaching and Teacher Education, Volume 28, Issue 3, 368-381. https://doi.org/10.1016/j.tate.2011.11.007

\section{Authors}

Suratno is vice dean and lecturer in Department Biology Education, Faculty of Teacher Training and Education, University of Jember, Indonesia (email : suratno.fkip@unej.ac.id )

Nurul Umamah is a lecturer in Department History Education, Faculty of Teacher Training and Education, University of Jember, Indonesia (email : nurul70@unej.ac.id)

Erlia Narulita is lecturer in Department Biology Education, Faculty of Teacher Training and Education, University of Jember, Indonesia(email : erlianarulita@ gmail.com) 
Paper-The Integration of Life-Based Learning Based Local Wisdom in the Development of Innovative...

Nurul Komaria is Doktoral of Sains Education Program, Faculty of Teacher Training and Education, University of Jember, Indonesia (email :nurulqomariah2202 @ gmail.com)

Khusnul Khotimah is Doktoral of Sains Education Program, Faculty of Teacher Training and Education, University of Jember, Indonesia (email : khotimahkhusnu 1000@gmail.com)

Article submitted 2020-05-14. Resubmitted 2020-06-24. Final acceptance 2020-06-25. Final version published as submitted by the authors. 